University of Michigan Law School University of Michigan Law School Scholarship Repository

1974

\title{
Delegate Selection Reform and the Extension of Law into Politics
}

Joseph Vining

University of Michigan Law School, jvining@umich.edu

Available at: https://repository.law.umich.edu/articles/1633

Follow this and additional works at: https://repository.law.umich.edu/articles

Part of the Election Law Commons, and the Law and Politics Commons

\section{Recommended Citation}

Vining, Joseph. "Delegate Selection Reform and the Extension of Law into Politics." Va. L. Rev. 60 (1974): 1389-413.

This Article is brought to you for free and open access by the Faculty Scholarship at University of Michigan Law School Scholarship Repository. It has been accepted for inclusion in Articles by an authorized administrator of University of Michigan Law School Scholarship Repository. For more information, please contact mlaw.repository@umich.edu. 


\section{VIRGINIA LAW REVIEW}

\begin{tabular}{lll}
\hline \hline VolUMe 60 & DeCEMBer 1974 & NUMBer 8 \\
\hline
\end{tabular}

\section{DELEGATE SELECTION REFORM AND THE EXTENSION OF LAW INTO POLITICS}

\section{G. Joseph Vining*}

$7 \mathrm{HE}$ fact that the 1972 presidential election introduced the formalities and some of the ideals of law into the gestation of national political power has been overshadowed by revelations about other aspects of the election campaign. But it will not be long before power will have to be organized and generated again from apartment blocks, meeting lalls, and coffee parties, and ultimately incarnated in another President. At some point hearing examiners for the National Democratic Party will appear again in various communities. Rules will be studied, records made, and appeals taken, all for the purpose of deliberately deciding who may participate in the process of cloosing the President. At this point it may well appear that the adoption of elaborate rules ${ }^{1}$ for the selection of delegates to the Democratic National

- Professor of Law, University of Michigan. B.A. 1959, Yale University; M.A. 1961, Cambridge University; J.D. 1964, Harvard University.

1 The 1968 Democratic National Convention authorized a Commission on Party Structure and Delegate Selection, which was established in 1969. Delegate selection rules set out in its report to the Democratic National Committee, Commission on PARTY Structure \& Delegate Selection, Mandate for Reform (1970), reprinted in 117 Cong. REC. 32908 (1971) [hereinafter cited as MANDATE FOR REFORM] were incorporated into the Call to the 1972 Convention, Democratic National Committee, Call for the 1972 Democratic National Convention, November 1971, and applied in 1972 credentials challenges. The 1972 Convention authorized a second Commission on Party Structure and Delegate Selection. Its report restating and revising the rules, was issued on October 27, 1973, and adopted with amendments by the Democratic National Committee on March 1, 1974. Democratic National Committee, Delegate Selection Rules for the 1976 Democratic National Convention, March 1, 1974 (mimeo) [hereinafter cited as Revised Rules]. This Article, following the terminology used by the Commissions, will designate the requirements of the 1973 Commission "Rules" and those of the 1969 Commission "Guidelines."

A number of the principles established by the rules for 1972 and 1976 have been incorporated in the Democratic Party charter adopted December 7, 1974. Unless amended by the National Convention, the charter will govern delegate selection rules after 1976. 
Convention was an event of more fundamental importance in the history of political democracy than even the recent impeachment proceedings.

Power is what much of law may be said to be about. "Private" governance by land owners and corporate directors and "public" decisionmaking by commissioners and cabinet officers is made possible by law. It does not trouble us to think that law indeed creates power. We look to legal processes to determine whether a person giving a command is speaking as an official or merely as a single human being asserting his personal prowess, and are accustomed to the quite complex notion behind the doctrine of ultra vires, which divides an individual into a number of roles and does not leave it to him to determine ultimately which role he has assumed when he acts.

Ideally, we determine that a person is speaking "as an official" by establishing that his command advances legislated values, shared values, public values, rather than merely his private values and personal desires. In a sense we depersonalize the command and seek to show that it comes from us, the sovereign. This is what we mean by the rule of law rather than of men. But there are large pockets of discretion in decision-making where the legal process cannot make this connection between what an official does and what we want to see done because there are no applicable legislated values. There, legitimacy depends not on what an official does but who he is. ${ }^{2}$ This may be the case with all officials whose decisions are in any way creative. ${ }^{3}$

Among the numerous substantive changes made in the rules in 1974, those designed to assure the inclusion of more party officials in the National Convention illustrate the natural growth of principles once they have been established. "At large" delegates from a state are authorized, and the state party Central Committee is authorized to select them, but only if the members of the Central Committee "have been elected through open processes in conformity with the basic procedural guarantees utilized for delegate selection." Revised Rules at 5 (Rule 12(2)). The result is to extend the impact of the rules beyond the "national" questions involved in the selection of a Presidential nominee and platform to the "local" matters principally handled by State Central Committees.

2 The law of public as well as private organization does recognize "de facto officials" in some circumstances. It is tempting to think that it makes no difference who is issuing an order so long as he is obeyed and is acting "legally." An example would be an imposter in police uniform successfully directing traffic. What this overlooks is how often we are limited in what we can say about the substantive legality of a particular decision.

3 This may include all officials. It is difficult to think of an official whose decisionmaking function is so mechanical that it involves no discretion. Whether there is a difference between the grand and "unreviewable" discretion of a President and the circumscribed freedorm of minor functionaries to choose factors to weigh and the weights to be given them should now be a moot point. After Citizens to Preserve Overton 
It is certainly the case with all legislative officials enacting new law, for by definition legislated values do not already exist to serve as a link between their decision and ours.

There are formalities involved in establishing "who" a person is for these purposes. Kings are anointed, ministers receive seals of office, senators are received into the Senate. But we have not, I think, viewed discretionary power as founded in law or created by it. We still demand a connection between the power-holder and ourselves, but the connection is outside the realm of law. The process by which individuals come to office, with their webs of personal connections and their particular resolutions of the conflicts of value at large in our society, has been treated as a necessary rough-and-tumble. There law has not ruled. The process by which men acquire authority has been a thing of nature, suitable for the attention of social science rather than law.

The establishment in 1969 of the Commission on Party Structure and Delegate Selection, and the issuance in 1971 by the Democratic National Committee of the Commission's "Mandatory Guidelines" to state parties for the selection of delegates, ${ }^{4}$ flattened this divide between life and law. The new rules were elaborate and enforced through elaborate quasi-judicial procedures. Violation of the rules, including failure to fulfill their affirmative mandates, did not result in conventional punishment. Violation meant that the "winner" might simply be found not to be a "delegate" at all. After adoption of the rules the political process within the Democratic Party could not be viewed as just happening. Voting delegates to party conventions with power to determine the either-or choice to be put to the electorate could no longer just "emerge," as for instance past leaders of the Conservative Party in Britain have "emerged" from a veiled and informal process. ${ }^{5}$ The existence of a "delegate" as a recognizable phenomenon became a matter of legal conclusion rather than a matter of fact.

Such an extension of law into politics expresses a major shift in perception. It is this that gives the new rules their general significance. Shifts in moral or intellectual perception may be largely irreversible,

Park, Inc. v. Volpe, 401 U.S. 402 (1971), discretion is that part of the decision-making process to which there is simply "no law to apply." 401 U.S. at $410,413$.

* See note 1 supra.

5 The 1969 Commission no doubt had in mind a similarly veiled process when it concluded that presidential candidates and national issues "clearly emerge" in the calendar year of the Convention and "characterize the politics" of the time. MANDATE FOR REFORM, 117 CoNG. REC. at 32914. 
as changes in visual perception often are. ${ }^{6}$ In any event, our minds are sufficiently bound together that shifts of this magnitude do not occur without affecting us all, Republicans as well as Democrats, and perhaps even members of democracies elsewhere who share our basic view of what sanctions the obedience of man to man.

\section{The Arrangement Before 1971}

The Democratic Party has always had "rules" for delegate selection, but before 1971 they were markedly different in form and substance. In form, they provided no forum for challenge except the credentials committee or the convention itself, which was necessarily a continuation of the mysterious rough-and-tumble. But this was of little consequence, for there were few rights for which remedies could be given. In substance, apart from requirements of party loyalty and prohibitions against gross and active racial discrimination the traditional

6 Cf. Julesz, Cooperative Pbenomena in Binocular Deptb Perception, 62 Am. Scr. 32 (1974).

[I]t takes some time before the random speckles [in a given example] suddenly form a well-known image. Usually, after such an image is recognized (i.e., after the transition to an ordered mental state) it is almost impossible to get rid of it ld. ...

When [an example of a stereogram] is first viewed ... it takes considerable time to perceive the surface in depth. However, after stereoscopic depth perception has been obtained, even years later fusion of this stereogram occurs almost instantly.

Id. at 32 fig. 1.

T See Mandate for Reform, 117 Cong. Rec. at 32911-14. The Republican rules were similar. P. David, R. Goldman \& R. Bain, The Polmtics of National Party ConvenTIONS 218-72 (1960).

8 State law and the state courts provide remedies for complaints such as vote fraud or bribery. But from the first to the most recent conventions, the national parties have taken the position that their seating decisions override those of state courts. See J. Campbell, Memorandum of Counsel to the 1972 Credentials Committee, June 23, 1972, at 3-9 (on file at offices of Virginia Law Review); Segal, Delegate Selection Standard̄s: The Democratic Party's Experience, 38 Geo. WAsh. L. Rev. 873, $873-79$ (1970). Cousins v. Wigoda, 415 U.S. 956 (1974), granting cert. to 14 Ill. App. 3d 460, 302 N.E.2d 614 (1973), will explore the relationship between national party autonomy and state sovereignty in a case involving criminal contempt charges authorized by Illinois courts against delegates who successfully challenged the winners of the primary in Chicago.

Federal remedies are available for gross racial discrimination, e.g., Terry v. Adams, 345 U.S. 461 (1953); Smith v. Allwright, 321 U.S. 649 (1944), but whether the federal courts will become part of the delegate selection process as it becomes formalized and increasingly susceptible to legal analysis remains to be seen. See O'Brien v. Brown, 409 U.S. 1 (1972); Kester, Constitutional Restrictions on Political Parties, 60 VA. L. REv. 735 (1974). 
arrangements for delegate selection allowed local party officials ${ }^{9}$ to select delegates. In states holding primaries, local officials frequently selected a slate of candidates, designated it the "official" or the "regular" or the "party" slate, and used the influence and resources of the permanent party campaign apparatus to secure its election. The "regular" slate might or might not be committed to a specific Presidential candidate. ${ }^{10}$

These arrangements threatened the unity of the Democratic Party, and thus the two-party system itself, ${ }^{11}$ after the riots at the 1968 Convention and subsequent loss of the election. They also threatened faith in political democracy. The first link in the chain between the only sovereign we recognize-the electorate, the people, ourselves-and the individuals exercising delegated powers over each of us on the sovereign's behalf, was perceived to be missing. Delegates determined who the presidential nominee would be. Party officials determined who the delegates would be. But the "rank and file" ${ }^{12}$ of the party did not determine who the party officials would be. There was no demonstrable connection between the officials and the rank and file, unless one makes it an article of faith that an individual retains power only because he is in fact representative.

Where party officials came to their positions through appointment by previous party officials, there simply was no connection to the source of legitimacy. And where party officials were elected, their

9 Illinois law, for example, requires that political parties establish municipal, county, and congressional district "central committees." IlL. Rev. Star. ch. 46, \$\$ 7-1 et seq. (1965). In Illinois there exist in addition "Regular Democratic Party Organizations" not provided for in the Election Code, but established as private associations under the nonprofit corporation act. These organizations have officials, and whether they were "Iocal party officials" for purposes of applying the national party rules became an issue adjudicated in the process of disposing of delegate challenges. See, e.g., Findings and Rulings of the Hearing Officer in the Challenge of Clancy and Sullivan to the Selection of Kirie, Shea and Toman as Delegates from the Sixth Congressional District of Illinois 44-46 (1972) [hereinafter cited as Hearing Report].

10 The variety of ways in which local party officials controlled the selection of delegates, either because of local rules or because there were no local rules, is surveyed in Mandate for Reform, 117 Cong. Rec. at 32911-14. See also Commission on the Democratic Selection of Presidential Nominees [the "Hughes Commission"], The DemoCRATIC CHOICE (1968).

11 Although one may speculate upon the possibility of a multi-party system as a viable solution to the problem of organizing a democracy, this discussion assumes a two-party system.

12 "Rank and file" was the Commission on Party Structure's designation for party members. Mandate for Reform, 117 Cong. Rec. at 32909. The rank and file, and particularly pluralities within it, are not "the people," but they are as close as one can get in an electorate organized into parties. 
election was perceived to suffer the very same defects-official selection of a slate and use of the party machinery to secure its electionthat afflicted the election of delegates. Furthermore, party officials maintaining the party organization between campaigns were elected for a wide variety of reasons-for instance, their executive, fundraising, or organizing capacities and interests. ${ }^{13}$ They were not necessarily elected as representative of the thinking of party members. No doubt good administration, or success in recruiting and organizing, depends to a considerable degree on a basic sympathy of outlook between the functionary and the rank and file. But our selection of a person for one reason does not mean we want him to speak on our behalf on all things. Certainly local party officials are rarely elected as representative of the thinking of the rank and file on national issues and national candidates. Insofar as they serve a representative function at all they focus on local issues, and they are generally chosen long before national presidential candidates emerge.

One may protest that these problems are cured, at least for the fundamental purpose of legitimizing the decisions of the President, by the President's direct election by the people. Even if we cannot say that the people freely choose their chief executive, we like to think that the President governs by the consent of the governed, who ratify the choice of the winning party. But a presidential election in a two-party system cannot be viewed as an expression of consent or ratification, in the way that a Senate vote for a nominee to the cabinet is viewed as a grant of consent to his assumption of power. The vote for the President is not "yes-no" but "yes-which," and we have no quorum rule. The sovereign in a democracy does not have even a veto, and cannot very well be allowed one if government is to be continuous. Once we recognize that people in power owe their power principally to earlier generations in the genealogy of officials, we can infer the consent of the governed, the sovereign, only from the absence of revolution or breakdown. That is not enough. Even slaves rarely revolt.

We could say there is no such thing as a sovereign, and that the legality of official decisions must be established by something other than reference to a sovereign will. But few have contemplated what the social fabric would be like if the notion of a sovereign were given up completely. ${ }^{14}$ I venture to say that in most of us the sense that we are free and that power is justifiable depends upon our assuming that

13 See Mandate for Reform, 117 Cong. Rec. at 32916 (Guideline B-2).

14 Cf. H. Hart, The Concept of Law 49-76 (1961). 
we can work back to a personified "we", to real and better selves within each of us that are ultimately identical. There is an enormous difference in the relative acceptability of power between believing that we obey or acquiesce principally because of the necessities of organized life, and believing that we obey because we obey ourselves. Definitions of law that do not include this dynamic element of joint responsibility and thus do not require a sovereign would not satisfy, and the lack of satisfaction would run at a level deeper than the intellectual. There is little choice but to forge that missing first link. ${ }^{15}$

\section{ThE New Rules}

\section{A. The Ideal of Openness}

The new rules limited the definition of "delegate" to persons who emerged from an "open" process of selection. They sought to break the circular and therefore "closed" process in which officials who had been chosen by previous officials chose those who would choose one of the two individuals who would become the President. With a delegate selection process open to the influence of party members generally, the quadrennial party convention was to become over time a representative and deliberative body, on the model of the Congress or a constitutional convention, rather than remaining a form of instruction and entertainment on the model of industrial or scholarly conventions. ${ }^{16}$

The notion of openness cannot be drawn analytically from the rules themselves. One rule, for instance, requires local parties to promulgate "explicit" and "written" rules governing "all aspects" of delegate selection. ${ }^{17}$ Clearly not just any collection of words on paper will do. At some point a challenger will point to a particular set of promulgated local rules and say that it violates the mandate because it is not

15 I am aware that in much contemporary legal discourse and academic discussion of legal institutions a concept of a general will is thought to be unnecessary. Whether that will continue to be the case as attention focuses upon early stages in the political process is open to question. Certainly insofar as consent is still generally thought to be necessary to the legitimacy of power, its apparent absence will always be likely to motivate reform, whatever reasons govern the choice of one proposed system over another.

16 This is not to say that conventions of this kind do not perform a serious and important function in the building of morale and a sense of common purpose.

17 Revised Rules at 1 (Rule 1A). Cf. Mandate for Reform, 117 Cong. Rec. at 32916 (Guideline A-5) (requiring "statewide Party rules and statutes which prescribe the state's delegate selection process with sufficient details and clarity" and "explicit written Party rules ... includ[ing] clear provisions"). 
explicit enough. Or a challenger will demonstrate that there are informal "rules" or patterns of behavior in a jurisdiction that violate the mandate because they are not written. An adjudicator will look in vain in the rules for a standard of openness to determine when local rules are explicit "enough" to achieve the purpose of the mandate or when an informal practice is "too important" to be viewed as supplementary and left unwritten. That standard is left to be developed, perhaps case by case. The notion of openness is inchoate.

It is also full of internal dilemmas. The rules require notice and an opportunity for party members to participate in all slate-making ${ }^{18}$ meetings in view of the fact that the stages at which choices are drastically narrowed are at least as important as the stage at which a final selection is made. Yet if groups of like mind on any party question other than the identity of a presidential candidate are to be able to organize themselves and thus bring their views to the point of serious debate within the party, they must be able to exclude from their deliberations spoilers of unlike mind. ${ }^{18}$

The rules impose special duties and limitations on "State Parties" and "official" action in an effort to neutralize the advantages" ${ }^{20}$ that persons in control of the permanent party structure have in affecting

18 Revised Rules at 2 (Rule 3(D), (E)); Mandate for Reform, 117 Cong. Rec. at 32917-18 (Guideline C-6). When delegates are chosen by caucus or a state convention of representatives of the rank and file, alternative slates of candidates are often prepared and presented, just as they must be prepared and presented to voters when the delegates are elected in a primary.

19 The dilemma was pointed up in Chicago, where the Hearing Examiner decided that the "regular" slate elected in the primary had been formed in secret meetings and was thus subject to replacement by the "reformers" who had challenged them. The regulars then joined the meetings of the reformers and elected themselves to the reform slate. See Chicago Daily News, June $24-25,1972$, 1, at 2, col. 1; Chicago Tribune, June $24,1972, \S 1$, at 4 , col. 1 .

20 The permanent party organization, tied to the community and active between as well as in presidential election years in the whole range of party affairs, can call upon loyalties and obligations among voters that ad hoc groups cannot. Voting for these reasons is not "irrational" from the individual's point of view, but it is nonetheless not upon the merits of the question on which the vote is elicited. This phenomenon cannot be prohibited. The only remedy is to see that the candidates given these powerful advantages through endorsement of the party structure are selected in an open way, that is, by obtaining the views of the voting rank and file before their sense of loyalty becomes operative.

The permanent structure also has advantages in established facilities and networks of party workers as well as information on the voting habits and the party affiliations of voters, not obtainable without the expenditure of much time and money. See Hearing Report at 35. 
the voting of the rank and file on national questions. But close examination of the party structure underlying the party organs established by state law often reveals permanent "private" organizations in which the advantages at stake actually reside and in which persons holding party posts under state law are involved "as individuals." ${ }^{21}$ Not to apply the neutralizing rules to such organizations is to let form prevail over substance and thwart the clear purpose of the rules. On the other hand, members of these ongoing organizations view themselves with some truth as a group of "friends and neighbors" of like mind. Applying special rules to them (by defining their organizations as part of the "State Party") may put them at a disadvantage vis-à-vis other ad hoc groups of party members seeking to affect the party decision, and thus reduce "openness." 22

These difficulties in attaining what we say is the object of the reforms illustrate the principal point I wish to develop. Openness or real democracy is at bottom what we say it is. In bringing under conscious control the initial stages in the creation of presidential power, the Democratic Party has sought to make democracy "real" on a very large scale, perhaps for the first time in history. The effort has revealed that there is no predetermined criterion of success, no end already defined to which our decisions are merely the means, no natural state of affairs which we will recognize when we see it. If we discover that there can be no democracy without cabals, then it is foolish to maintain an ideal of democracy without cabals. Once the process of structuring is begun the ideal of democracy is no longer a useful guide; and it is unclear what can legitimately guide us in our decision-making, since the structuring of democracy involves the very definition of what the sovereign will is. We are on uncharted seas both in designing and in construing legal rules.

Nonetheless, the Democratic Party has undertaken to make authoritative and responsible decisions, and not at a single stroke as in a constitution after a revolution, but continuously. ${ }^{23}$ After a look at two

21 Cf. Hearing Report at 44-46.

22 There is no less a dilemma if the problem is cast in terms of party unity itself rather than openness as a means to unity. If the special advantages of the permanent party structure are not neutralized, there are strong incentives for various groups within the party to establish rival permanent structures that might rapidly grow into new parties. But if the particular group active in the permanent party organization is disadvantaged as such, it too has an incentive to break away, with perhaps equally serious results.

${ }^{23}$ The making of a constitution after a revolution poses the same problem but only for a short time. Revolutions are infrequent, and after constitutions are made they 
further aspects of the new rules, I will suggest that what has happened is not unique, and is understandable as an instance of a more general experience which can be recognized in personal as well as social life. I will also suggest that the effort will go forward, simply because it is so very difficult to move from a state of knowledge to a state of ignorance.

\section{B. Enforcement}

To resolve local disputes over delegate selection, the new rules ${ }^{24}$ provided for hearings in the local community before an uncommitted and uninvolved examiner designated for that purpose by the national party executive. ${ }^{25}$ The one hundred and fifty member credentials committee would decide, on the basis of the examiner's findings, whether a violation had occurred and what remedy would be appropriate. The convention itself retained power to accept or reject the committee's decision.

The effect of these provisions was to judicialize the decision-making process. Just as the committee reports carried weight with the quite obviously unjudicial convention, the hearing examiners' findings with respect to violations of the rules presented the committee, as never before, with crystallized statements of "the merits." A presumption ran in favor of their correctness, as against contrary decisions of the committee, simply because of the procedure that lay behind them. ${ }^{26}$

enter people's minds as a given, defining the sources of authority in an ultimate way. Here we may be engaged in a continuous process of creating a constitution.

24 There were two documents containing procedural rules in 1972. One, entitled "Rules of Procedure of the Credentials Committee of the 1972 Democratic Convention," appeared as part of the Call for the convention issued by the Democratic National Committee. 1972 Call, supra note 1, at 15-24. The other, entitled "Guidelines for Hearings," was issued by the acting chairman of the credentials committee of the convention as an elaboration of Rule 5 of the "Rules of Procedure," and covered matters such as expenses, discovery, burden of proof, and powers of the hearing officer.

25 The institution of a more effective enforcement procedure as part of the substantive reforms did not mean that the national party or its examiners were set against local party officials, or vice versa. Though reducing local power over one aspect of party activities, the rules were designed to preserve a party in which local officials would continue to find it worthwhile to be officials.

There were conflicts, of course, particularly in the Chicago challenge where the first hearing examiner withdrew and the second was somewhat abused. Chicago Tribune, June 1, 1972, § 1A, at 8, col. 1. Significantly, however, in the related Illinois Sixth Congressional District challenge involving similar parties and virtually identical issues, relationships were as cordial as can be expected in an adversary proceeding, and the conduct of both the regular party delegates and the challenging parties was admirably professional.

26 Such a presumption is formalized in the law of judicial review of administrative 
The committee could not reject too many reports without facing the question whether it was not rejecting the rules themselves. The revised 1974 rules took judicialization one step further with the creation of a Compliance Review Commission to serve as a "Prehiminary Credentials Committee." ${ }^{2 \pi}$

As before, the process of challenge led to a determination of who should be seated as a delegate. The "sanction" for violation of the rules was a determination that the person who emerged from the selection process calling himself a delegate was "not a delegate." 28 The problem of replacing delegates at a stage when the selection process could not be started over again was left largely unresolved. ${ }^{29}$ But the nature of the remedy made quite clear the definitional quality of the rules even though part of the definition might be missing.

Consequently, the rules of procedure applicable in challenges assumed enormous importance. Insofar as the inquiry was whether a person was a delegate, any rule that affected the outcome of that inquiry became

agencies. See Fishgold v. Sullivan Drydock \& Repair Corp., 328 U.S. 275, aff'g 154 F.2d 785 (2d Cir. 1946) (L. Hand, J.).

27 Revised Rules at 8 (Rule 19), 11-13.

28 The quo warranto, or one might even say quasi in rem, nature of the proceeding was indicated by the provisions of the "Rules of Procedure," supra note 24, that permit challengers to proceed against selected individuals or groups of delegates as they choose rather than against the state delegation as a whole (rules $1(b), 2)$ and that do not require that challengers be seeking delegate seats themselves (rules 2(a), (c) (iii)). Furthermore, individual delegates chosen as respondents by challengers had the burden of defending actions or omissions of the state party, see Letter from Donald $M$. Fraser, Chairman of Commission on Party Structure and Delegate Selection, to Lawrence F. O'Brien, Chairman of Democratic National Committee, November 29, 1971, at 2; Hearing Report at 8-13, which they could not control and in which they might or might not have been personally involved. The fairness of the burden thus placed on individual delegates may be questioned. But the procedures did have the advantage of keeping the definitional purpose of the rules clearly in view and helped preserve the work of the Credentials Committee in devising remedies appropriate to the various situations (including censure, pledges for the future, vote reduction, split seating, and selective substitution of challengers, alternates or others, see Campbell, supra note 8, at 29-53) from slipping into an inappropriate conceptual framework of personal rights and duties.

${ }^{29}$ See, e.g., Revised Rules at 10 (Rule $19(\mathrm{H})$ ):

In the event the Delegate Selection Plan of a State Party is found to be in default or non-compliance and such default or non-compliance is not remedied by corrective action by the time the first stage of the delegate selection process has begun, it shall be the duty of the Executive Committee of the Democratic National Committee to constitute a committee from that State, to propose and implement a process which will result in the selection of a delegation from the affected State which shall (1) be broadly representative, (2) reflect that State's division of presidential preference, and (3) involve as broad a participation as is practicable under the circumstances. 
definitional too. Questions such as the timeliness of challenge, the adequacy of service, the necessity of joinder or severance, the burden of proof, the scope of discovery and the sanctions for refusal to disclose, even the allocation of the costs of the proceeding, were raised in the course of the challenges and had to be resolved one way or another. The consequences of their resolution in a particular case were clear enough to the participants, and public awareness of the consequences has followed. ${ }^{30}$ The addition of the enforcement mechanism which the elaborate substantive rules made necessary has meant that "structural" considerations inevitably affect and even determine who is to be the representative.

One might well ask how this situation differs from that which existed before the infusion of elaborate and consciously chosen rules, where "structural" factors also determined who acquired power. The answer is simply that the procedural rules are determinants for which we are responsible, whereas the determinants we perceive in the rough and tumble are not. If we treat the consequences of formality as costs, we can weigh them against the gains we achieve from the "reform" as a whole, and where we have choices-for instance, having decisions turn in some cases on burden of proof may be inevitable, but where the burden should lie is a matter of choice-we can design them to serve our larger substantive ends and thus be in a position to affirm that we have for the moment chosen the more rational alternative.

\section{Affirmative Action}

As part of opening the delegate selection process the new rules required local party organizations to go beyond non-discrimination and take affirmative action to bring in "traditionally underrepresented" groups-particularly, blacks, women, and the young. ${ }^{31}$ The effort caused immense controversy. In the minds of many the reforms were identified with that alone, and the 1972 Convention itself was widely viewed as the product of reverse discrimination. The second Commission on Delegate Selection and Party Structure, the Mikulski Commission, was heavily occupied with the problems of affirmative action: whether it was possible to avoid slipping into quotas; which underrepresented groups needed special attention and which needed only the removal of barriers; and whether in view of the never-ending ways of defining a group any formal search for "underrepresented" groups

30 Cf. Revised Rules at 13.

31 See note 47 infra. 
would inevitably frustrate the more important objective of opening up the delegate selection process and the convention.

But the problems posed by the mandate to overcome the effects of past discrimination with affirmative steps were' not essentially different from the problems that have arisen in similar programs outside the political party, in education, housing, or employment. Their resolution by those charged with implementation of the mandate-party officials in the first instance, then hearing examiners, party commissions, and the Credentials Committee itself-has been and is likely to be drawn from experience with similar, ongoing programs elsewhere which are under continuous litigation and legislative review. The development of the rules in this respect is likely to move with the larger currents at work.

Thus the movement from non-discrimination in 1964-68 to affirmative action in 1968-72 is not in itself noteworthy. It would have been surprising rather if there had been no such movement. Nor are the analytic, practical, and, indeed, political problems engendered by it at the 1972 Convention noteworthy as such. The injection of an enforceable affirmative action program is certainly symptomatic, and I will return to it in the end; but concentration on it in and for itself can only obscure what is distinctive about the substance of the reforms.

\section{The Significance of Questioning the Legitimacy of Elected Delegates}

It may be helpful now to refer to a particular challenge under the new rules with which $I$ have some personal familiarity..$^{32}$ The respondents in the 1972 proceedings in the Sixth Congressional District in Illinois were three of the six winners of a primary election. Two of the respondents were "Township Committeemen," occupying elected positions on party organs established by state law. Both also headed their townships' "Regular Democratic Organizations," non-profit corporations not mentioned in the party structure outlined in Illinois law, with permanent headquarters and established networks of precinct captains and party workers. Both occupied posts in municipal govern-

32 The familiarity is drawn from service as Hearing Examiner in the challenge after it had been severed from the larger Cook County challenge which became of such legal and political importance. Keane v. National Democratic Party, decided sub nom. Brown v. O'Brien, 469 F.2d 563 (D.C. Cir.), stayed, 409 U.S. 1, vacated sub nom. Keane v. National Democratic Party, 409 U.S. 816 (1972), dismissal of complaint aff'd, 475 F.2d 1287 (D.C. Cir. 1973); Cousins v. Wigoda, 463 F.2d 603 (7th Cir.), stay denied, 409 U.S. 1201 (1972); Wigoda v. Cousins, 14 Ill. App. 3d 460, 302 N.E.2d 614, cert. granted, 415 U.S. 956 (1974). 
ment, one being the County Coroner and the other a Metropolitan Sanitary District Trustee. The third respondent was the assistant leader of the State Party in the Illinois House of Representatives. All three were uncommitted to a presidential preference. The challengers were two party workers who had similarly campaigned as uncommitted candidates in the primary election, but had received insufficient votes to put themselves in the top six. As women they were bringing the challenge with the support of the National Women's Caucus.

The hearing examiner found that the State Party had not fulfilled its affirmative duty to ensure open slate-making and that party officials had privately prepared a full slate of candidates and instructed the Regular Organizations to campaign for it. The examiner also found that inadequate steps had been taken to fulfill the affirmative action mandate of the rules with respect to women. The two township officials were found to be personally involved in the failure to fulfill the affirmative duties imposed on them as party officials and in the secret slate-making prohibited by the rules. The leader of the House was found to be personally uminvolved. The Credentials Committee adopted the hearing examiner's findings and recognized the two challengers as delegates in place of the two township officials.

The respondents' principal defense was that they had received more votes than the challengers in an election conducted without a hint of vote fraud. This was repeated from time to time throughout the proceeding, and the accuracy of the statement was never questioned. Yet as the hearing went on it became clear that the very existence of the proceeding-the court reporter, the hearing examiner, counsel for the opposing sides, the submission of documents, the challenges to the relevancy of evidence and the arguments over burden of proof and the meaning of phrases in the rules-was a rejection of this basic claim to legitimacy. Who were the delegates, if a question was raised, was to be determined only through the proceeding, and the proceeding was focused on something other than whether each individual tallied in the vote count did in fact cast his vote in that way. What that something was could not be as simply stated. If asked, the participants could do no more than point to a complex set of published rules, and say that "the question" was whether what had been done before the election by a large number of individuals was consistent with the rules.

It was also clear to the participants that they could not approach that question without addressing further sets of complex questions whose answers would determine the conclusions of substance: To what extent 
should respect be given to the decisions of other authorities in similar cases? ${ }^{33}$ To what extent should settled points be reopened? At what point might an inference be properly drawn from suggestive patterns of circumstance, and what weight should be given to those values that would be harmed if the inference were drawn and those that would be harmed if it were not? To what extent should the parties be allowed to develop strategies against each other without interference by a presiding officer charged with making findings? What inferences could properly be drawn from a lack of rebuttal? These questions become relevant whenever law enters a field of action. The participants, the respondents included, turned naturally to them and were able to argue each of them pointedly.

The application of the delegate selection rules to primary states as well as caucus and convention states involves a recognition in the political sphere of truths with which corporate and securities lawyers-those concerned with the creation of power in the "private" sphere-have worked for decades. There is no magic in an election. Its outcome can be determined by the few in ways that depend not at all on bribery (if we exclude the fraternal back-scratching that prevents the few from fighting too much among themselves) and sometimes bear no taint of impropriety. The American law of private organization contains a concept of "corporate democracy" 34 in pursuit of which the legal system has taken notice of control of the electoral process and attempted to develop effective remedies against it. The remedies in-

${ }^{33}$ The Sixth Congressional District case was one of first impression, like all 1972 challenges. Only in 1976 and later election years will hearing examiners and review commissions be able to look to precedents directly applicable. They are likely to do so for the sake of the planning, reliance and sense of fairness which consistency protects, as well as for want of time and money to do otherwise. In 1972, questions of consistency arose in connection with disputes over the "authority" of pronouncements interpreting the rules made by national party officials such as the acting chairman of the credentials committee, the chairman of the Democratic Central Committee or the chairman of the Commission on Party Structure. Parties also referred to the treatment of substantive questions in other areas of law, such as what constitutes concerted action or what inference of personal knowledge can be properly drawn from the mere fact of a person's position in a hierarchy of responsibility.

34 Participation is confined to shareholders, and the majority of shares rather than the majority of shareholders controls. However, built on the notion of accountability to an electorate are a variety of remedies that protect corporate constituencies other than shareholders, see, e.g., Superintendent of Insurance v. Bankers Life \& Cas. Co., 404 U.S. 6 (1971), and influence outcomes without regard to relative property interests. See, e.g., Mills v. Electric Auto-Lite Co., 396 U.S. 375 (1970); Schwartz, Tbe Public Interest Proxy Contest: Reflections on Canpaign GM, 69 Mrch. L. Rev. 419, 479-82 (1971). 
clude ousting elected management after a vote has been taken and the corporate sovereign appears to have spoken. ${ }^{35}$

I do not wish to suggest that there has been any conscious importation of thinking from the private to the public sphere. But I think it is fair to say that as law enters the process of creating political power at its roots, the marvelously simplifying notion that, in a democracy, the vote of the people is the last word and settles questions of legitimacy for better or worse, will fade. The line of legitimacy is seen no longer to run directly from elected representatives, or, more accurately, holders of power, to the massed electorate. It is seen rather to run through a further set of individuals who have power to influence or manipulate the outcome of the election. Whether they have authority to do what they do becomes then a matter of law, and with it the legitimacy of the power and position of the chosen representative becomes a matter of law also. ${ }^{36}$

In the end only two viable choices are presented in a presidential election. Hundreds, probably thousands, and in some sense millions of alternatives have been excluded in the course of reaching that point

35 See 2 L. Loss, Securities Regulation 956-73 (2d ed. 1961). Cf. J.I. Case Co. v. Borak, 377 U.S. 426 (1964); Laurenzano v. Einbender, 264 F. Supp. 356 (E.D.N.Y. 1966); Kohn v. American Metal Climax, Inc., 322 F. Supp. 1331, 1366 (E.D. Pa. 1970), modified, 458 F.2d 255 (3d Cir.), cert. denied, 409 U.S. 874 (1972).

36 This is ground for criticism of the comments on remedies in Raymar's excellent article, Judicial Review of Credentials Contests: The Experience of the 1972 Democratic National Convention, 42 Geo. WAsh. L. Rev. 1, 35-39 (1973). Mr. Raymar seems to attribute inherent significance to the existence of a cast vote, and suggests that constitutional problems are raised by the replacement or dilution of the power of delegates elected in a primary, because of impairment of the voting rights of those who elected them. There is no reason to assume that constitutional protection of voting rights must take the vote as a given and ignore the process of which it is a product, any more than the law of trade must accept consumers' purchases as an expression of their true and free choices and ignore the process of persuasion and the limitations on alternatives which produced the purchase.

Even if it is assumed that cast votes must be viewed axiomatically as the will of those who vote, no easy analytic conclusion follows. In giving effect to one person's right to the suffrage, due account must be taken of another's right to participate meaningfully in the process leading to the vote. Cf. Kusper v. Pontikes, 414 U.S. 51, 58 (1973):

Under our political system, a basic function of a political party is to select the candidates for public office to be offered to the voters at general elections. A prime objective of most voters in associating themselves with a particular party must surely be to gain a voice in that selection process. By preventing the appellee from participating at all in Democratic primary elections during the statutory period, the Illinois statute deprived her of any voice in choosing the party's candidates, and thus substantially abridged her ability to associate effectively with the party of her choice. 
in the expression of the popular will. It is meaningless of course to ask what the ultimate grantors of power would have done if their choice had not been so restricted. Alternatives must be progressively removed from consideration and the possibility of choice to achieve organization of any kind. But it is equally neaningless to claim that because the electorate have chosen one of the alternatives presented to them, it is "their choice" and that is that. If there is to be any real connection between the mind of the ultinute governor and the "mind" of the governed, it must be found in the process by which the alternatives are excluded and the ultimate choice conies to be formulated. ${ }^{37}$

We may well prefer to leave that process to the rough and tumble of "real life," the raw competition of personalities, values, and shifting coalitions of wills and moods beyond analysis and beyond control. We may prefer not to touch it, just as we fear to touch free speech. We are not irrational in having faith that the right result will come out of this generative chaos and that the result that does come out is right because it is the result of the process and for no other reason. But if we see that the process is in fact governed by rules, that it is subject to analysis and is under the control of particular individuals in society, then we can no longer unquestionably accept the outcome as that of "history" or "social forces" or whatever else it is we use to designate the mysterious complexities of life. At the very least, our perception forces us to ask whether the operative rules and the role of the power holders are tbemselves an unfathomable expression of the popular will and the current resolution of "social forces"; or whether, instead, they constitute an artificial distortion of the popular will which we have the responsibility to correct.

Take the example of the urban political machine. It is entirely possible that the interposition of a machine between urban masses and their decision-making representatives accommodates unmet social and psychological needs, such as the need for additional security in sickness, old age, and unemployment, or the need which immigrants especially may have for a sense of belonging or of vicarious power. Quite apart from the exercise of political power, the machine may serve functions for which "the people" would if they thought about it, and per-

37 One can conceive of other connections. It is doubtless true that after individuals enter positions of power they may seek to reflect what they conceive to be the popular will. A populace may discover in a given leader a reflection of their views or even be molded to the view of the leader. But there is no way of demonstrating that such ex post facto harmonies exist. Resort to them is an apologetic for the fact that there is no a priori connection in which we have confidence. 
haps inarticulately do, gladly sacrifice some of the purity of the democratic ideal. Observers who take the long view often come to some conclusion of this kind. ${ }^{38}$ Who are we to gainsay the people's choice in this matter? Even if we wish to intervene, we cannot be certain that the machine is any more than a symptom of more fundamental social forces. How can we suppose that a phenomenon with such roots in social reality would not crop up again in another form if we sought to cut it out of our political system?

On the other hand, it is also possible that the power of members of the machine is nothing more than a consequence of the laws we happen to have, and that there is no reason to believe that the situation will change within an acceptable period of time unless we choose to change it. The reasons for the machine and the imperfections in democracy it represents may not be grand and deep, but technical-the nature of the districting, for example, or the use of the "unit rule," ${ }^{39}$ or the affording of recognition to decisions of "meetings" held without notice and with low quorum rules. We may even call such reasons "arbitrary," the situation being an unforeseen and unintended but (with hindsight) inevitable by-product of devices enacted for quite different purposes. And once we have that knowledge, are infected with it so to

38 E.g., R. Merton, Social Theory and Social Structure 73 et seq. (enlarged ed. 1968).

39 A "unit rule" requires all members of a delegation to cast their votes in accordance with the will of the majority of the delegation. It is the equivalent in political institutions of the holding company in the control structures of private corporate organizations. A series of applications of the unit rule, like a series of holding-companies, can produce minority control.

There is of course nothing natural about a holding company. It is purely a creation of law. There is nothing unnatural about a system that does not recognize holding companies. The Delaware Corporation Act grants corporations plenary authority to hold the voting stock of other corporations, see DeL. CoDE ANN. tit. 8, $\$ 123$ (1953), the German Corporation Act limits and regulates the power of one corporation to control another, see German Stock Corporation Act $\$ \$$ 308-18 (F. Juenger \& L. Schmidr transl. 1967), and the Federal Public Utility Holding Company Act of 1935 modifies and in some cases eliminates power to control derived from state legislation in the public utility field, see 15 U.S.C. $\$ \$ 79(\mathrm{i})-(\mathrm{k})(1970)$. The 1972 California Credentials Challenge, see Brown v. O'Brien, 469 F.2d 563 (D.C. Cir.), stayed, 409 U.S. 1, vacated as moot, 409 U.S. 816 (1972), was a protest to the application of a unit rule. That the outcome of the convention may have turned on this challenge points up the degree to which the sovereign will is a product of the consciously chosen structure for its expression.

The delegate selection rules prohibit the unit rule. Revised Rures at 3 (Rule 8). The rules also deal with quorum requirements and proxy voting, see id. at 2 (Rules 6 and 7), matters familiar to corporate law and litigation as ingredients of control structures. 
speak, we are burdened with responsibility, for the situation is the result of our own creations and we can change it if we will. If we do not change it we choose to have it continue, and are put to the task of justifying it to ourselves, something we never have to do with matters beyond our control.

Thus if the way in which political power is created is really beyond our comprehension, however much we may talk about and study it, we cannot be troubled by it. We accept what is tossed up and begin our analysis of democratic legitimacy from that point. But if we can identify the sources of power and find that they are within the legal system itself, then we are faced with an unavoidable choice. If the way in which candidates are chosen and alternatives narrowed is not really veiled in ignorance, it is very difficult to distinguish laissez-faire from approval and deliberate continuation of the situation. ${ }^{40}$ The continuous public discussion of the legitimacy of power that is the prime characteristic of a free society tends to press behind what had been its starting point before, and if justifications are not forthcoming the very sense of legitimacy and acceptance of power begin to suffer. Consequently, we must decide to leave the situation as it is and to justify it, or to change it and justify the change. We pull the matter out of the realm of the given, the hard facts of life, and into the realm of law,

40 The notion of laissez-faire is a difficult one for lawyers to understand. Lawyers live continuously with challenges to social and economic relations which reveal the omnipresence of the coercive powers of the state. Cf. Calabresi \& Melamed, Property Rules, Liability Rules, and Inalienability: One View of the Catbedral, 85 Harv. L. REv. 1089 (1972).

In the Chicago delegate challenge, cases cited note 32 supra, it seemed at first that the successful challengers alone owed their position to "intervention" and the deliberate exercise of coercive power-by the hearing examiner, the credentials committee, and the United States Court of Appeals for the District of Columbia. Much was made of this "intervention" in political commentary and rhetoric. The Supreme Court sought to leave the question a "political" one and remove the law from responsibility for the outcome by staying the court of appeals' decision to affirm the action of the credentials committee. See O'Brien v. Brown, 409 U.S. 1; 4 (1972). But the defendants in the delegate challenge obtained from the Illinois courts a decision granting them the positions they sought and enjoining the challengers from bringing the challenge, and the state of Illinois has since proceeded to enforce that grant by seeking criminal sanctions against the challengers individually for taking the positions for themselves in violation of the court order. Wigoda v. Cousins, 14 Ill. App. 3d 460, 302 N.E.2d 614, cert. granted, 415 U.S. 956 (1974). Thus it was revealed that whoever occupied the delegate's chair would owe his position to the active use of public power-ultimarely, the power to jail-on his behalf, and thus the issue which the Supreme Court sought to avoid as non-legal has been raised in legal form. 
where what exists is a product of the will and little is given save the inherited and shared system of concepts that guide our thought. ${ }^{41}$

In the event, the Democratic Party chose not to sanction the present system, and began experimenting with specific devices to bring about change. What precisely those devices are, whether they work or in fact have effects of little consequence, whether they are internally consistent, whether they have unintended and perhaps undesirable effects in operation, what substantive considerations or objectives are to be taken into account in resolving disputes about their enforcement and interpretation, whether they are enforced, and what the pattern of their enforcement is-all these are matters of the greatest importance. They will be the substance of analytic and legislative work in the future. But the principal significance of the new rules does not lie in the details of their substance, in what they specifically command or forbid. It is the prior choice, the choice to take responsibility for the process of selection of delegates to the national convention, to raise the very question of the legitimacy of the process and to produce answers, temporary or "permanent," adequate or inadequate, that makes the appearance of the rules an event of such great importance. Of course, this kind of choice is presented continuously in private as well as public life-whether to leave a subject matter to drift and evolve or to exercise control over it, whether to shift from an observing and descriptive frame of mind to a critical and moral one. But when the subject matter is the creation of political power the choice is of constitutional significance.

Why control shauld have been asserted at this point in time $I$ can only venture to speculate. It is noteworthy that it was asserted first with regard to the presidency, even though the same problems arise in the

41 The familiar example is the decision by the federal judiciary that the drawing of voting district lines by state legislatures unrepresentative of urban populations in such a way as to ensure that the legislature remained unrepresentative did not present a "political question." Baker v. Carr, 369 U.S. 186 (1962). The decision to take responsibility for the mechanics of the system by which state legislatures are created is not the consequence of the appearance of any easy or ingenious solution to the substantive problems. An effort has been made to invest the rule of "one man, one vote" with an axiomatic quality, but, as in delegate selection reform, representative democracy is the ultimate object and one man, one vote does not automatically produce it: scattered minorities, for instance, may end up without any representation at all. Cf. Liebman, Social Intervention in a Democracy, The Public INTerest Number 34, Winter 1974, at 21-22. This outcome, once perceived, is as much a product of deliberate choice as the lack of representation of urban groups would have been had the system been left as it was before. 
selection of party candidates for election to the Senate or the House. The growing concern about party unity and the maintenance of parties as organizing forces in political life crystallized in the demonstrations of the 1968 presidential campaign. The President is the symbolic and effective head of the party, and nourishing the roots of his power is perhaps the first and most important contribution to unity. More importantly, the realization that the President has grown to be far more than an executive and now directs much of the course and content of national legislation has made it difficult to refrain any longer from questioning and exercising control over his selection. Those who feel that they do no more than ratify the deliberations of unseen rulers when they vote for a legislative representative, and that the member from their district has little necessary connection with them, can at least look elsewhere in the legislature for spokesmen for the values they hold important. They cannot do this in the case of the President. To maintain a sense that they are indeed represented and have in some sense participated in and consented to the public developments that are brought about by the institution of the presidency, they can look only to the process of lis selection.

\section{The Selection Rules as an Example of the Extension of LAW}

It may seem surprising to talk of the entry of law now, when, as I have noted, there were party rules before the first Commission on Party Structure. If a previous rule allowed party officials, themselves selected by party officials, to select delegates, and defined as a "representative" the person selected by such a process, and the new rules do no more than define as a "representative" a person selected by a different process, why has there not been simply a shift in the rule by which a "representative" is recognized?

The answer lies in what I have suggested is the truly significant and (in politics) novel substantive position contained in the new rules, that there is no magic in an election. There may have been an awareness before of the part authoritarian selection played in the outcome, but the inquiry into the legitimacy and acceptability of the outcome was not pushed behind the election. The election was the starting point, curing defects, stopping questions. In pushing the inquiry back to the earlier stages of the process, the Democratic Party became responsible for the party "rules of recognition" as it had never been before. And 
it is responsibility, the sense of conscious choice, that indicates the entry of "law" where there had been only "rules" before.

Responsibility calls forth elaborateness and comprehensiveness in the system of explicit rules. Our recognition of the "winner" of an election depends upon our acceptance of majority rule. If enforced by public force when challenged, majority rule becomes a rule of law. But if that were the only rule we perceived, I do not think we would say that the emergence of political power was subject to "law." We know that the process is governed by too many other "factors." We think of the outcome as the product of external, social causes. Given its subject matter, our rule would have too little "substance." The same is true of previous delegate selection rules. They were not elaborate. The new rules are, to the point that we see them as a formal system. And formality tends to have something of a life of its own, reinforcing as well as expressing the sense of responsibility that called it forth.

An elaborate set of rules requires organized institutions of enforcement. Their very complexity precludes disorganization in thinking about and applying them. Moreover, at a certain point of elaborateness substantive questions not explicitly addressed by the rules can nonetheless be thought about within their terms. For example, the new rules in their present form impose duties on "State Parties," 42 impose apparently different requirements for "official" and other meetings in the delegate selection process, ${ }^{43}$ and prohibit the unit rule or any equivalent "practice" within any "party unit" at "any stage of the delegate selection process." 44 Of what or whom does the "State Party" consist? Are the meetings of "Regular Democratic Organizations" continuously in existence between elections but organized as private nonprofit corporations or clubs, to be treated as "official," or as no different from meetings of ad hoc groups supporting a particular candidate or political position? Are all meetings of party members meetings of a "party unit?" Such questions of substance will in all probability arise in 1976, just as they arose in 1972. Arising within the context of the rules they can be brought to the decision-making institutions created with the rules. Indeed we can expect them to be inescapable in the disposition of a challenge, and whether the institutions of enforcement (the hearing examiners, the Compliance Review Commission, and the Credentials Committee) themselves supply the answer in the

42 E.g., Revised Rules at 1 (Rules 1, 2).

43 Compare id. at 2 (Rules 3(B), (C)) with id. at 2 (Rules 3(D), (E)).

44 Id. at 3 (Rule 8). 
first instance or refer the matter to bodies such as the Convention that are more broadly legislative, the answer must be a chosen one and a conscious one, for which responsibility cannot be denied.

A system of rules is not likely to be elaborate without covering or attempting to cover the field. The new rules are no exception. It is too difficult, too apparently futile, to engage in the careful deliberation that formal decision-making within a system of rules requires if the outcome in which one is interested is perceived to be governed by factors beyond the scope of consideration. It is done, to be sure, particularly in economic regulation. Administrative agencies. from the Interstate Commerce Commission to the Federal Reserve, deal with various aspects of the economic system without subjecting the system as a whole to comprehensive regulation. But significantly, we do not think of the economic system as subject to "law," even though each economic phenomenon may be the product of $a$ law-a doctrine of property law, an institution of labor law, a provision of the law of corporations or of agency. On the other hand, when economic matters are pulled together from time to time in the administration of central controls over prices and incomes in response to inflation, we immediately see and say that "law" has entered the picture. We also for the first time face and feel responsible for the outcome-for instance the distribution of the immediate fruits of economic efficiency and enterprise among labor, the consumer, and the contributors of capital-as we seek to make consistent and justifiable choices. ${ }^{45}$

It may even be fair to say that we are not fully conscious or aware of the existence of a rule, such as the former party rule that delegates might essentially be selected by party officials, until it has been pulled into a comprehensive code and placed beside other rules. It is easy to observe that there are rules of recognition, dependent on legal definitions, underlying the phenomena of every social field of action. But it is questionable whether we grasp them as such unless we address

45 For a provocative account of the British experience by the former Chairman of the Prices and Incomes Board, suggesting that permanent adjudication of questions heretofore left to the discretionary determination of business managers or the bargaining of powerful social institutions may be necessary in view of the causes of inflation, see A. Jones, The New Inflation: The Politics of Prices and Incomes (1973).

It is instructive (and startling) to look at the substance of litigation in the United States with respect to particular decisions in the administration of the wage-price freeze and exemptions from it. See, e.g., Anderson v. Dunlop, 366 F. Supp. 582 (D.D.C.), rev'd on procedural grounds, 485 F.2d 666 (Temp. Emer. Ct. App. 1973), cert. denied, 414 U.S. 1131 (1974). Questions are posed for practical resolution that have been among the most difficult and troubling in ethical and political debate. 
them in an organized and formal way. We may have to be comprehensive to be conscious, as the ambiguity in the word "comprehension" suggests.

I now return to that part of the content of the new delegate selection rules, the affirmative action programs for "traditionally underrepresented groups," which I suggested were not essential to the historic importance of the rules, but were nonetheless symptomatic. ${ }^{46}$ Affirmative action represents the most formal possible definition of legitimacy. Whether or not it is in the form of a system of quotas, affirmative action requires the outcome of a particular stage in the creation of political authority to be measured against a prior determination of what is acceptable. There is no agnosticism with respect to the outcome, and little room for belief that the outcome of a designed process is correct simply because it is the outcome of that process. Full responsibility for the consequences is accepted-and demanded. The underlying shift in perception of political matters is evident.

But as the Democratic Party draws back to a less certain statement of what constitutes an "unbalanced" delegation or Convention, ${ }^{47}$ we also

46 See p. - supra.

47 Guideline A-1 (2) required:

that State Parties overcome the effects of past discrimination by affirmative steps to encourage minority group participation, including representation of minority groups on the national convention delegation in reasonable relationship to the group's presence in the population of the State.

Mandate for Reform, 117 Cong. Rec. at 32915.

Guideline A-2 required the same for women and persons between the ages of 18 and 30. Id. The 1969 Commission ruled that:

[W] henever the proportion of women, minorities and young people in a'delegation ... is less than the proportion of these groups in the total population, and the delegation is challenged on the grounds that Guidelines $A-1$ and $A-2$ were not complied with, such a challenge will constitute a prima facie showing of violation of the Guidelines, and the state Democratic Party along with the challenged delegation has the burden of showing that the state party took full and affirmative action to achieve such representation ....

Letter, supra note 28 , at $1-2$.

The revised rules provide:

(1) The goal of such Affirmative Action shall be to encourage such participation in delegate selection processes and in Party Organizations at all levels of the aforementioned groups as indicated by their presence in the Democratic electorate. (2) This goal shall not be accomplished either directly or indirectly by the Party's imposition of mandatory quotas at any level of the delegate selection process or in any other Party affairs. B. Performance under an approved Affirmative Action Plan and composition of the convention delegation shall be considered relevant evidence in the challenge of any State delegation, but composition alone shall not constitute prima facie evidence of discrimination, nor shall it shift the burden of proof to the challenged party. If a State Party has adopted and implemented an approved Affirmative Action Program, the Party 
see that responsibility and absolute control do not go hand in hand. We answer questions and make choices because we must. But we are in a rolling system, in which prior answers and choices generate new questions and choices, apparently without end, and there seems no possibility of a gradual exhaustion of questions to be settled or a gradual freezing of thought and society into patterns dictated by current values. If we draw back from an authoritative definition of the human characteristics to be represented in a representative body-age, sex, occupation, religion, culture-it is because we know that our definition is inadequate, even though we cannot provide an alternative and say what an adequate definition is. What we know is that there is much yet to discover within us. Again we confront a mystery, as intriguing and comforting as the mystery of an external rough-and-tumble. The difference is that we can be free of whatever we discover within simply by agreeing that we will be free, and thus push ourselves on to the next question, the next choice. That is the nature and extent of our control. It is far from absolute, but it is enough to make us responsible.

shall not be subject to challenge based solely on delegation composition or primary results.

REVISED RULES at 7-8 (Rules 18(A) (1), (2); 18(B)). 